Article

\title{
Structural, Morphological, Optical and Electrical Characterization of Gahnite Ferroan Nano Composite Derived from Fly Ash Silica and ZnO Mixture
}

\author{
Sushree Saraswati Panda ${ }^{1}$, Hara Prasada Tripathy ${ }^{1}$ D, Priyabrata Pattanaik ${ }^{1}$, , Dilip Kumar Mishra ${ }^{1}$, \\ Sushanta Kumar Kamilla ${ }^{1}$, Asimananda Khandual ${ }^{2} \mathbb{D}$, William Holderbaum ${ }^{3} * \mathbb{D}$, Richard Sherwood ${ }^{4} \mathbb{D}$, \\ Gary Hawkins ${ }^{4}$ (D) and Shyam Kumar Masakapalli ${ }^{5}$ (D)
}

check for updates

Citation: Panda, S.S.; Tripathy, H.P.; Pattanaik, P.; Mishra, D.K.; Kamilla, S.K.; Khandual, A.; Holderbaum, W.; Sherwood, R.; Hawkins, G.;

Masakapalli, S.K. Structural,

Morphological, Optical and Electrical Characterization of Gahnite Ferroan Nano Composite Derived from Fly Ash Silica and $\mathrm{ZnO}$ Mixture. Materials 2022, 15, 1388. https:// doi.org/10.3390/ma15041388

Academic Editors: Krzysztof Talaśka, Szymon Wojciechowski and Antoine Ferreira

Received: 16 December 2021

Accepted: 31 January 2022

Published: 14 February 2022

Publisher's Note: MDPI stays neutral with regard to jurisdictional claims in published maps and institutional affiliations.

Copyright: (C) 2022 by the authors. Licensee MDPI, Basel, Switzerland. This article is an open access article distributed under the terms and conditions of the Creative Commons Attribution (CC BY) license (https:/ / creativecommons.org/licenses/by/ $4.0 /)$.
1 Semiconductor Research Laboratory, Faculty of Engineering and Technology (ITER), Siksha 'O' Anusandhan (Deemed to be University), Bhubaneswar 751030, India; ss.sushreesaraswati@gmail.com (S.S.P.); hara345@gmail.com (H.P.T.); priyabratapattanaik@soa.ac.in (P.P.); dilipmishra@soa.ac.in (D.K.M.); sushantakamilla@soa.ac.in (S.K.K.)

2 Department of Textile Engineering, Odisha University of Technology and Research, Ghatikia, Bhubaneswar 751029, India; asimte@cet.edu.in

3 School of Biological Science, Biomedical Engineering, University of Reading, Whiteknights RG6 6AY, UK

4 Infrared Multilayer Laboratory, Atmospheric, Oceanic and Planetary Physics, Clarendon Laboratory, Parks Road, Oxford OX1 3PU, UK; richard.sherwood@physics.ox.ac.uk (R.S.); gary.hawkins@physics.ox.ac.uk (G.H.)

5 School of Basic Sciences, Indian Institute of Technology Mandi, Kamand, Mandi 175005, India; shyam@iitmandi.ac.in

* Correspondence: w.holderbaum@reading.ac.uk

\begin{abstract}
The synthesis of a high value-added product, gahnite ferroan nano composite, from a mixture of fly ash silica and $\mathrm{ZnO}$ is a low-cost and non-expensive technique. The XRD pattern clearly reveals the synthesized product from fly ash after leaching is a product of high-purity gahnite ferroan composite. The grains are mostly cubical in shape. The optical band gap of powdered gahnite ferroan nano composite is $3.37 \mathrm{eV}$, which acts as a UV protector. However, the bulk sample shows that the 500 to $700 \mathrm{~nm}$ wavelength of visible light is absorbed, and UV light is allowed to pass through. So, the bulk sample acts as a band pass filter of UV light which can be used in many optical applications for conducting UV-irradiation activity. Dielectric permittivity and dielectric loss increase with a rise in temperature. The increase in the ac conductivity at higher temperatures denotes the negative temperature coefficient resistance (NTCR) behavior of the material.
\end{abstract}

Keywords: fly ash; ZnO; gahnite ferroan; band pass filter; NTCR

\section{Introduction}

Gahnite ferroan, $(\mathrm{Zn}, \mathrm{Fe}) \mathrm{Al}_{2} \mathrm{O}_{4}$, is a mineral present in small amounts in rock but has no bearing on the classification of the rock, similar to zircon in granite. A volcanic eruption has metamorphosed the mineral sulfide ore bodies by creating gahnite with different impurities, such as iron and magnesium [1]. This also occurs as the segregations in quartz veins and quartzo-feldspathic rock. Gahnite is present throughout the mineralized zones and thus contains pyrite, sphalerite, chalcopyrite and sulfosalts. This mineral has been found naturally in so many places [1-5] starting from in the Falun mine (Sweden), Wind River Mountain (Wyoming, United States), Silberberg mine (Bavaria, Germany), near Parelhas (Rio Grande do Norte, Brazil), Wodgina and Greenbushes (Western Australia), Victoria Range (Nelson, New Zealand) and the Mamandur area (Tamil Nadu, India). Due to globalization, these rare minerals are in the last stage of vanishing. Recreating this type of mineral for different applications is the prime objective of this research work, by implementing the waste management techniques to form value-added products such as gahnite ferroan. 
Pulverized fuel ash (PFA), fly ash (FA) or coal combustion residuals (CCRs) are produced from coal-fired boilers with flue gases. Coal firing started in the 1920s for thermal power generation, as a result of which millions of tons of FA and related by-products have been produced worldwide over the past century [6,7]. As a result of the huge production of FA and its toxic behavior, the recycling of FA has become a primary concern in the climate of clean environmental economies. A large portion of FA has been utilized for making cement [8], but still, a huge amount of residual FA is dumped in landfills [9] and ash ponds [10]. The composition of FA and its impact on the environment [6] is instigating researchers to work extensively on the reformation of these materials for different potential applications. For several decades, FA has been utilized as concrete [11], bricks [6], geopolymer [12,13], a low-cost absorbent for the removal of organic compounds [14,15], poison gas [16], water treatment $[17,18]$, earth filler and the synthesis of zeolite. FA has also been utilized in the agricultural sector as a fertilizer to increase the productivity of the soil, in paints and enamels, wood substitute composites, floor tiles and wall tiles [19]. A wide variety of compounds are found in the composition of $\mathrm{FA}$, including silicon dioxide $\left(\mathrm{SiO}_{2}\right)$, aluminum oxide $\left(\mathrm{Al}_{2} \mathrm{O}_{3}\right)$ and iron oxide $\left(\mathrm{Fe}_{2} \mathrm{O}_{3}\right)$. Elements such as manganese $(\mathrm{Mn})$, zinc $(\mathrm{Zn})$, nickel (Ni), lead (Pa) and arsenic (As) are found predominantly in different forms of fly ash, depending on the production method. The above traceable compounds can be further modified, and the altered end product utilized in different potential applications [20-23].

In particular, zinc oxide $(\mathrm{ZnO})$ has been chosen to alter the FA from its base nature to form rare minerals. Zinc aluminate (gahnite, $\mathrm{ZnAl} 2 \mathrm{O} 4$ ) is a rare mineral formed due to the alteration product of sphalerite ( $\mathrm{Zn}, \mathrm{Fe}) \mathrm{S}$ compositions). A wide energy band gap of $3.8 \mathrm{eV}$ (large absorbance in UV region) and chemical stability in high-temperature environments are all useful properties for researchers to investigate. Aluminum-based spinels depict an intriguing group of oxide ceramics with diverse applications [24]. Among these, gahnite prominently serves as a pigment, in optoelectronics and as a transparent semiconductor, a photo catalyst, and a ceramic material [21-23,25-30]. An enormous number of applications can be possible by using gahnite as the base material. In this research article, a method is performed to synthesize gahnite ferroan by utilizing a mixture of FA and $\mathrm{ZnO}$. The utilization of FA is an entirely new and novel application of this research work. Structural, morphological, optical and electrical characterizations are carried out to confirm the formation and different properties of gahnite ferroan.

\section{Experimental Section}

Fly ash (FA) with a specific gravity of $2.20 \mathrm{~g} / \mathrm{cm}^{3}$ on ignition (LOI: $2.90 \%$ ) was procured from the National Aluminum Company Limited (NALCO), Angul 759145, Odisha, India. The quantification of various compounds present in the fly ash was analyzed by a chemical route and is listed in Table 1.

Table 1. Quantification of various compounds present in the fly ash.

\begin{tabular}{cc}
\hline Compound & Quantification (wt \%) \\
\hline $\mathrm{SiO}_{2}$ & 57.13 \\
\hline $\mathrm{Al}_{2} \mathrm{O}_{3}$ & 34.24 \\
\hline $\mathrm{CaO}$ & 2.84 \\
\hline $\mathrm{MgO}$ & 0.91 \\
\hline $\mathrm{Fe}_{2} \mathrm{O}_{3}$ & 2.78 \\
\hline $\mathrm{K}_{2} \mathrm{O}$ & 0.65 \\
\hline $\mathrm{TiO}_{2}$ & 0.91 \\
\hline
\end{tabular}

Similarly, zinc acetate $\left(\left(\mathrm{CH}_{3} \mathrm{COO}\right)_{2} \mathrm{Zn} \cdot 2 \mathrm{H}_{2} \mathrm{O}\right)(98 \%)$, ethylene glycol $\left(\mathrm{HOCH}_{2} \mathrm{CH}_{2} \mathrm{OH}\right)$ (99\%), glycerol $\left(\mathrm{C}_{3} \mathrm{H}_{8} \mathrm{O}_{3}\right)(98 \%)$, 2-propanol $(\mathrm{CH} 3 \mathrm{CHOHCH} 3)(99 \%)$, triethylamine $\left.\left(\mathrm{C}_{2} \mathrm{H}_{5}\right)_{3} \mathrm{~N}\right)$ $(99 \%)$ and nitric acid $\left(\mathrm{HNO}_{3}\right)(70 \%)$ from Emplura, Merck, were purchased commercially for the synthesis of $\mathrm{ZnO}$ sol-gel without further purification, and they have CAS numbers 
of 557-34-6, 107-21-1, 56-85-1, 67-63-0, 102-71-6 and 7697-37-2, respectively. The chemical route technique was employed to form $\mathrm{ZnO}$ sol-gel. For the synthesis of $\mathrm{ZnO}$ in sol-gel form, zinc acetate $(9.74 \mathrm{~g})$, ethylene glycol $(25 \mathrm{~mL})$ and glycerol (12 drops: $6 \mathrm{~mL})$ were mixed and stirred using a magnetic stirrer with a fixed bed temperature of $130{ }^{\circ} \mathrm{C}$, until a transparent solution without any granular particles was obtained. While cooling down to room temperature, 2-propanol $(42 \mathrm{~mL})$ and triethylamine $(11 \mathrm{~mL})$ were added in the mixture and the solution was continuously stirred for $15 \mathrm{~min}$. The solution was transferred to a $500 \mathrm{~mL}$ beaker and placed in a sand bath with the bed temperature maintained at $200{ }^{\circ} \mathrm{C}$ [31]. In lukewarm conditions, fly ash (10 g) was added and stirred using a glass rod to remove lumps before the beginning of the pyrophoric process with the addition of triethylamine $(5 \mathrm{~mL})$ and nitric acid $(10 \mathrm{~mL})$, respectively for reaction process propagation. The continuous bed temperature led to the redox mixture leaving behind ample amounts of carbon-containing powder. The collected sample was ground and underwent calcination at $1300{ }^{\circ} \mathrm{C}$ for $5 \mathrm{~h}$. The carbon-free sample was collected and underwent hydrofluoric leaching at a ratio of 1:5 with distilled water for each $2 \mathrm{~g}$ of carbon-free sample for $7 \mathrm{~h}$. After the leaching, the sample was collected through filtratrion (Whatman filter paper). The wet filter paper was kept in an oven for $3 \mathrm{~h}$ at $200{ }^{\circ} \mathrm{C}$ and then in a furnace for $5 \mathrm{~h}$ at $600{ }^{\circ} \mathrm{C}$. After this process, the final product was found to be $0.76 \mathrm{~g}$ out of $2 \mathrm{~g}$ of leached synthesized powder.

\section{Characterization}

X-ray diffraction patterns of the prepared sample were performed utilizing Rigaku Ultima-IV to study the crystal structure, with radiation $1.5406 \AA$ ( $\mathrm{Cu} \mathrm{K} \alpha$ source) wavelengths on $2 \theta$ ranging from $20^{\circ}$ to $80^{\circ}$ at room temperature. Scanning electron microscopy (FEI company of USA (S.E.A) PTE LTD, model- Nova Nano SEM-450) and transmission electron microscopy (FEI company of USA, model- FP5022/22-Tecnai G220 S-TWIN) were carried out to study the three- and two-dimensional structures, along with the average grain size of the produced sample. The Nova Nano SEM-450 was equipped with backscattered electron and secondary electron detectors and an EDAX energy-dispersive X-ray spectrometer. Fourier transform infrared (FTIR) spectral analysis wavenumber ranging from $350 \mathrm{~cm}^{-1}$ to $7800 \mathrm{~cm}^{-1}$ were scanned utilizing a FT-IR 4600 instrument (Japan Spectroscopic Company). Transmittance, absorbance and semiconducting properties were analyzed by implementing UV-VIS-NIR spectrum analysis (Jasco V-750 spectrophotometer, Japan). The precision of the instrument was enhanced by double beam optics with a variable spectral bandwidth. The dielectric and electrical properties were analyzed by recording the AC parameters, such as capacitance $(C)$, loss tangent $(\tan \delta)$, impedance $(Z)$, and phase $(\theta)$ using an LCR meter (NF model ZM2376, Japan).

\section{Results and Discussion}

In order to visualize the sample formation, X-ray diffraction pattern analysis was carried out. Figure 1 illustrates the stacked individual X-ray diffraction patterns of (a) before-leaching, and (b) after leaching, respectively. The hydrofluoric acid leaching had a prominent impact on the purity and thus is clearly visible in Figure 1a,b. After leaching, the pattern in Figure $1 \mathrm{~b}$ shows the pure form of the produced sample. Without any baseline correction, the pattern was matched with standard database \# 82-1582. This reveals the mineral name, along with the empirical formula of the formed composite. Gahnite ferroan $\left(\mathrm{Al}_{1.995} \mathrm{Fe}_{0.339} \mathrm{O}_{4} \mathrm{Zn}_{0.599}\right)$ belongs to the cubic crystal system. From inter planar spacing, the Scherrer equation and reference \#82-1582, the lattice constant, crystallite size and volume of the unit cell were calculated. The lattice constant with the unit cell volume of gahnite ferroan are well matched with the reference values reported in JCPDS \# 85-1582, and the calculated values are 8.8114 $\mathrm{A}, 532.22 \AA$ and $8.2991 \AA, 571.60 \AA$, respectively. The calculated average crystallite size of the gahnite ferroan sample is $40.15 \mathrm{~nm}$. The observed lattice strain of the sample is $8.143 \times 10^{-6}$, which is calculated from a Williamson-Hall plot. 


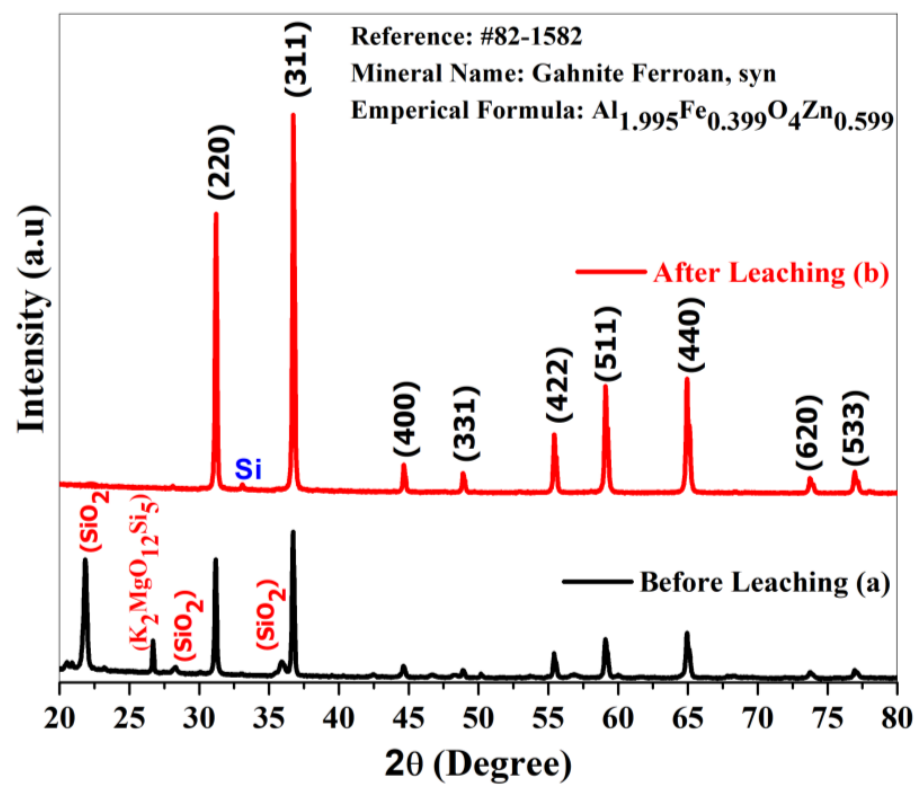

Figure 1. X-ray diffraction pattern of gahnite ferroan composites (a) before leaching and (b) after leaching obtained powder sample within Bragg's diffraction angles of $20^{\circ}$ to $80^{\circ}$.

Surface morphology, structural appearance, texture, and chemical composition of the samples were visualized using scanning electron microscopy in conjunction with an EDS system. Figure 2a shows the produced sample before leaching at $4.3 \mathrm{k}$ mag and $7.99 \times 10^{-3}$ $\mathrm{pa}$, with a scale size of $20 \mu \mathrm{m}$, Figure $2 \mathrm{~b}$ after leaching obtained powder sample at $12 \mathrm{k}$ mag and $3.72 \times 10^{-3} \mathrm{pa}$, with a scale size of $10 \mu \mathrm{m}$, and Figure $2 \mathrm{c}$ bulk sample, with a scale size of $10 \mu \mathrm{m}$. The energy-dispersive X-ray pattern with a smart quant table depicts the material composition in or on the surface for quantitative information. The EDS pattern with the elemental smart quantization table is illustrated in Figure 3. The weight percentage values of the elements $\mathrm{O}$ (oxygen), $\mathrm{Z}$ (zinc), $\mathrm{Al}$ (aluminum) and $\mathrm{Si}$ (silicon) are 30.23, 31.25, 10.06 and 28.47 , respectively. The sample also underwent transmission electron microscopy for the visualization of internal structure and particle size analysis. Figure 4 shows the TEM image of the gahnite ferroan composite.The average particle size of gahnite ferroan is $460 \mathrm{~nm}$.

The FT-IR spectrum of a prepared gahnite ferroan powder sample is shown in Figure 5. The most useful infrared region lies between $650 \mathrm{~cm}^{-1}$ to $4000 \mathrm{~cm}^{-1}$ since this radiation region induces the vibrational excitation of the functional groups. Above $3300 \mathrm{~cm}^{-1}$, there is no observation of any stretching or bending modes of vibration in the gahnite ferroan powder sample. Hence, Figure 5 denotes the wavenumber ranges from $550 \mathrm{~cm}^{-1}$ to $3300 \mathrm{~cm}^{-1}$. In the FTIR spectrum, sums of seven peaks are noticeable. The vibration modes of C-H bonds are observed at two positions of the wave number at $600 \mathrm{~cm}^{-1}$ and $640 \mathrm{~cm}^{-1}$. Another band appears at $950 \mathrm{~cm}^{-1}$, indicating the vibration modes of RCO-OH. There is observation of three stretching modes of vibrations at $670 \mathrm{~cm}^{-1}, 1500 \mathrm{~cm}^{-1}$ and $1734 \mathrm{~cm}^{-1}$ assigned to $\mathrm{C}-\mathrm{Br}, \mathrm{Ar} \mathrm{C}-\mathrm{C}$ and $\mathrm{C}=\mathrm{O}$ stretch modes, respectively. The modes of vibration at $2357 \mathrm{~cm}^{-1}$ indicate a P-H phosphine group. After diluting the materials in distilled water, the aqueous solution exhibits an alkaline $\mathrm{pH}$ value of 8.92. The optical absorption spectrum of gahnite ferroan is depicted in Figure 6a,b in a broad spectral range of $200 \mathrm{~nm}$ to $800 \mathrm{~nm}$. The UV-visible spectrum of the prepared gahnite ferroan powder sample discloses two distinct absorption peaks at $288 \mathrm{~nm}$ and $363 \mathrm{~nm}$. Absorption peaks arise due to band transition from the valence band to the conduction band. The direct band gap energy is determined by interpreting the plot between $(\alpha \mathrm{h} v)^{2}$ and $(\mathrm{h} v)$. The calculated direct band gap energy of gahnite ferroan is $3.37 \mathrm{eV}$. Figure $6 \mathrm{~b}$ depicts the comparative spectral study between the powder sample and the bulk sample. In powder form, the filtrate region is under ultraviolet wavelengths of light $(280 \mathrm{~nm}-290 \mathrm{~nm})$. In the case of the bulk form, the filtrate range $(500 \mathrm{~nm}-680 \mathrm{~nm})$ shifts toward the visible region with a prominent flat line of 
complete absorption. Beyond $850 \mathrm{~nm}$ to $2600 \mathrm{~nm}$ wavelengths, light is absorbed completely. As the bulk sample is processed using high-temperature sintering processes, grain growth occurs. A higher grain size reduces the optical band gap, for which both large grain and grain boundary are sensitive to absorb the particular wavelengths of light (500-680 nm).
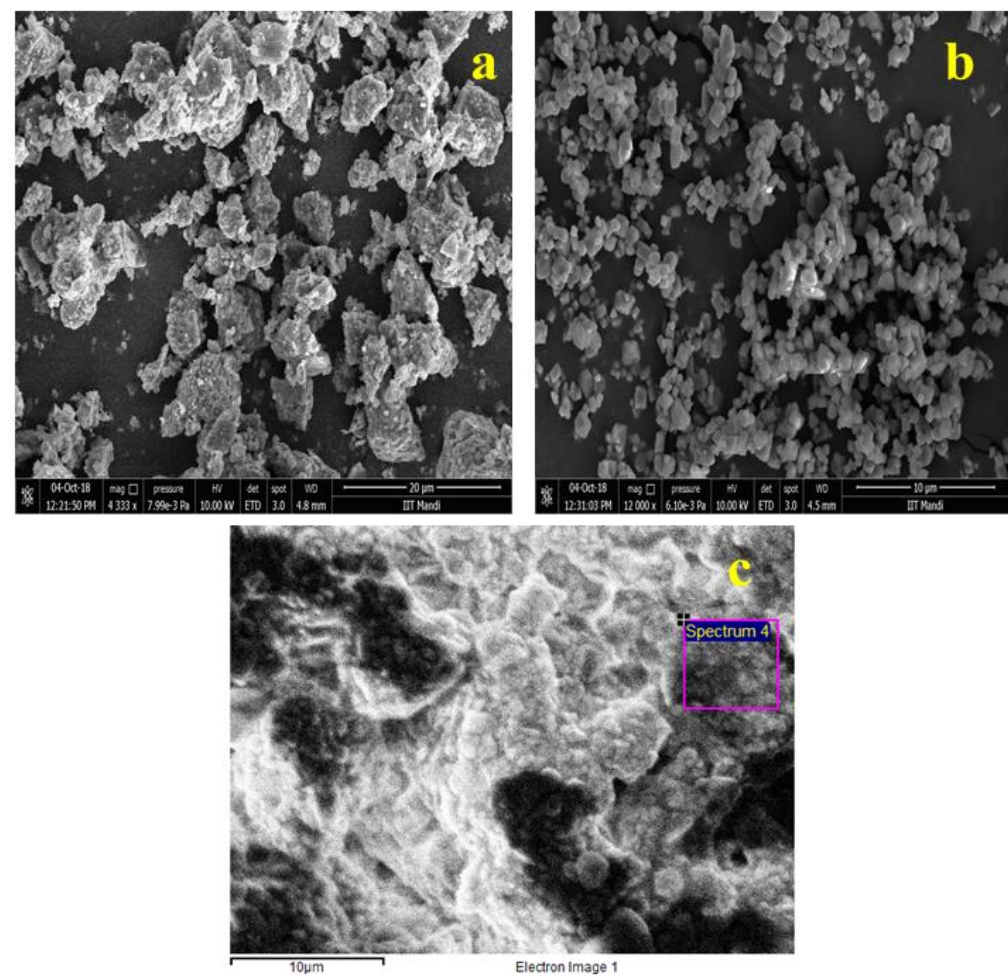

Figure 2. Scanning electron micrographs of gahnite ferroan composites (a) before leaching at $4.3 \mathrm{k}$ mag and $7.99 \times 10^{-3} \mathrm{pa}$, with scale size $20 \mu \mathrm{m}$, (b) after leaching, obtained powder sample at 12 $\mathrm{k}$ mag and $3.72 \times 10^{-3} \mathrm{pa}$, with scale size $10 \mu \mathrm{m}$, and (c) bulk sample, with scale size $10 \mu \mathrm{m}$.

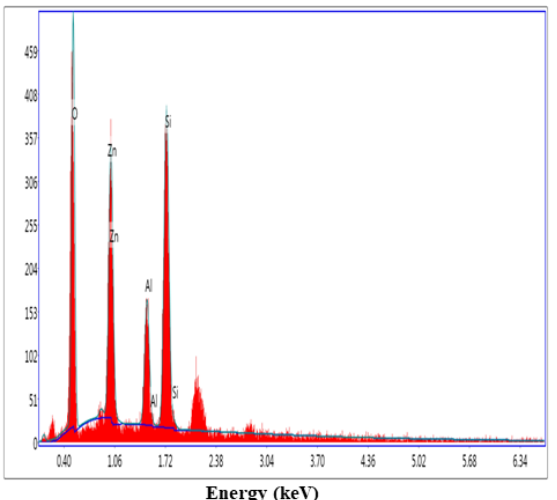

(a)

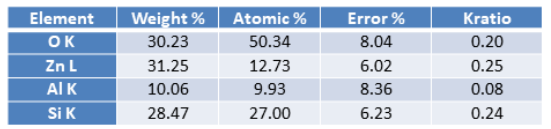

(b)

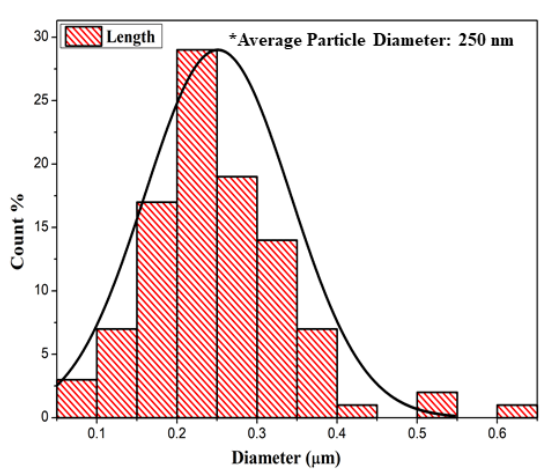

(c)

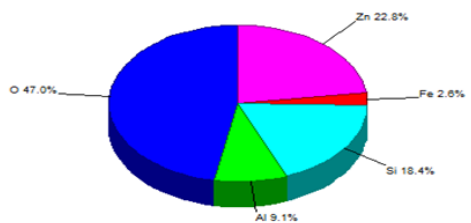

(d)

Figure 3. (a) Energy-dispersive X-ray patterns of gahnite ferroan composites; (b) particle size distribution of gahnite ferroan composites; (c) elemental analysis of gahnite ferroan composites; and (d) quantitative weight percentage of bulk gahnite ferroan composite. 


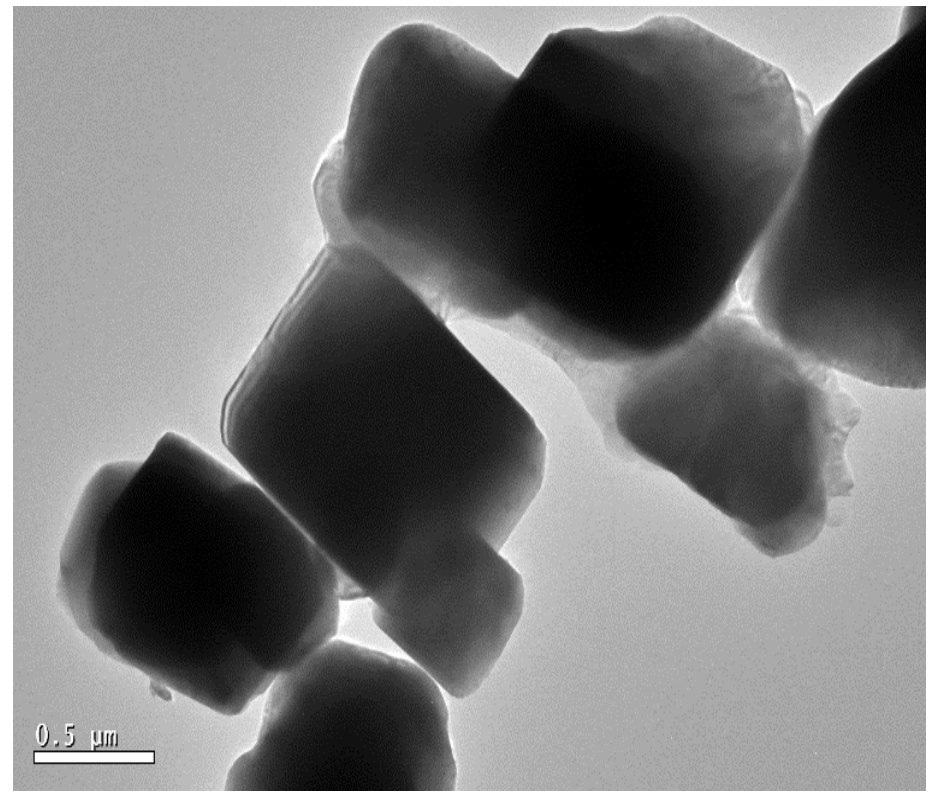

Figure 4. Transmission electron microscopic image of gahnite ferroan composite.

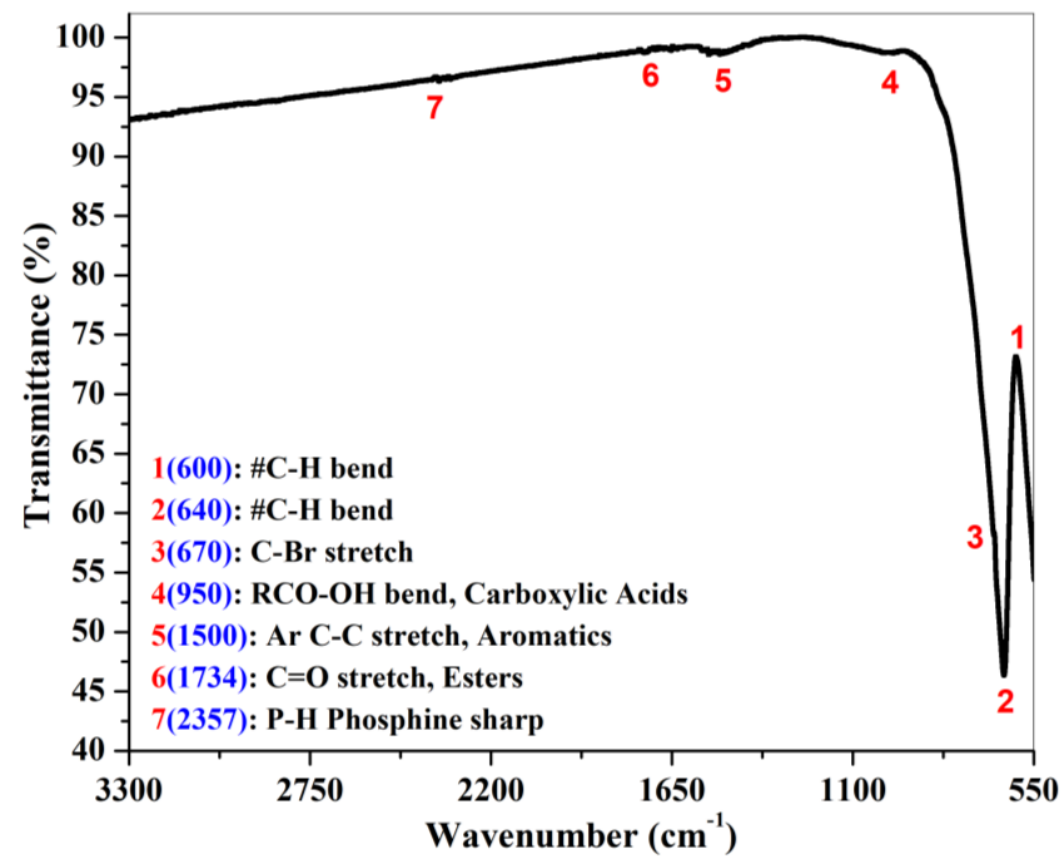

Figure 5. Fourier-transform infrared (FTIR) spectrum of gahnite ferroan composite. 


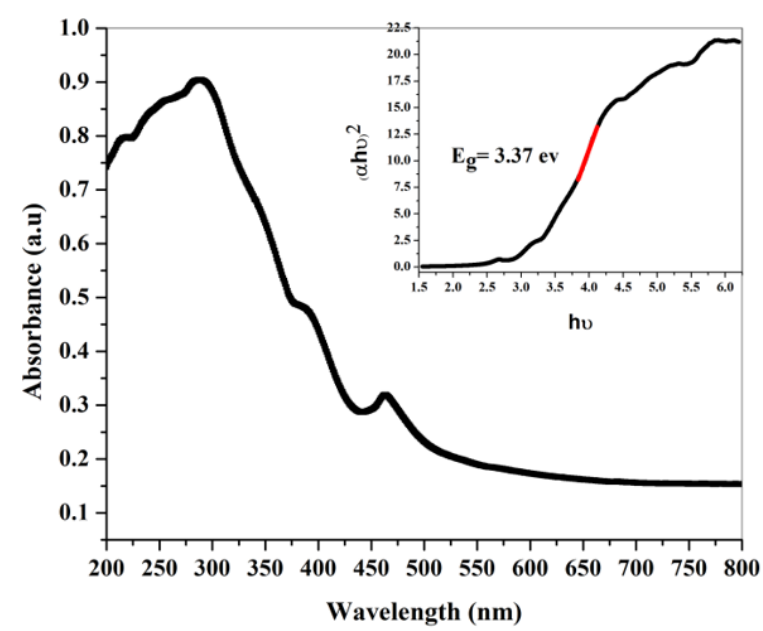

(a)

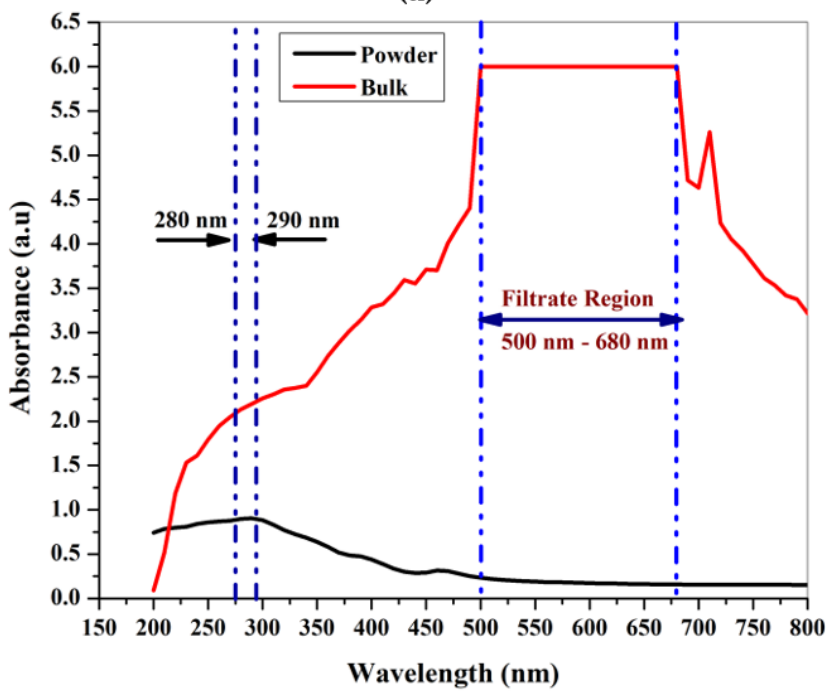

(b)

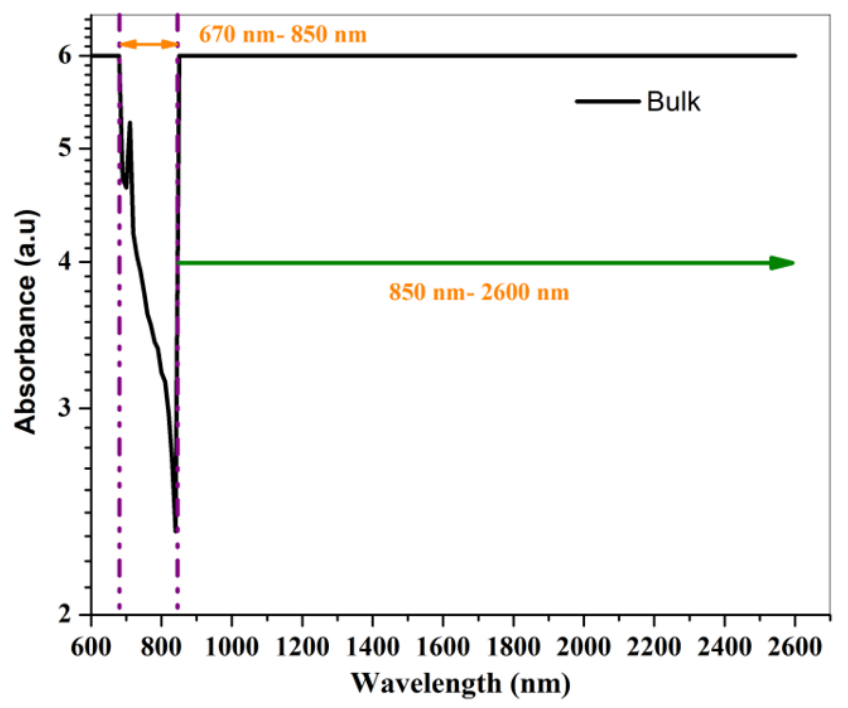

(c)

Figure 6. UV visible NIR spectra of (a) gahnite ferroan composite in powder form; (b) gahnite ferroan composite in powder and bulk form for comparative study and (c) gahnite ferroan composite of bulk sample beyond $600 \mathrm{~nm}$ wavelength. 
After leaching, the produced gahnite ferroan is free from impurities and is not detected under the instrumentation limit. So, to use the powder in a final product, it may be coated over a substrate or directly made into a bulk form (pellet) to characterize its electrical properties. The bulk form of the sample was made directly from gahnite ferroan powder by using a hydraulic pallet press (Kimaya Engineers, Thane, Maharashtra, India) at 8 tons of pressure, for a standard time of $5 \mathrm{~min}$. The thickness and diameter of the pellet was $2 \mathrm{~mm}$ and $13 \mathrm{~mm}$, respectively.

The dielectric and electrical properties were analyzed by recording the AC parameters such as capacitance $(C)$, loss tangent $(\tan \delta)$, impedance $(Z)$, and phase $(\theta)$ using an LCR meter (NF model ZM2376, Japan). The LCR meter analysis of the dielectric materials is based on the principle of the electrical circuit (RC circuit) modeling of dielectric materials. Each dielectric can be polarized by application of an external electrical field and has capacitance, $C=\frac{\varepsilon_{0} \varepsilon_{r} A}{d}\left(\varepsilon_{0}\right.$ : permittivity of free space, $\varepsilon_{r}$ : relative permittivity/dielectric constant of the dielectric material taken, $A$ : cross-sectional area of the specimen, $d$ : the thickness of the specimen). For the electrical measurement of the gahnite ferroan, the pellets of $2 \mathrm{~mm}$ thickness were silver pasted and made conductive. The two opposite surfaces of the pellet, which are silver pasted, act as electrodes. The pellet was placed in a furnace using a sample holder which was connected to the LCR meter. Then, the AC parameters were recorded in a frequency range of $10 \mathrm{~Hz}-100 \mathrm{KHz}$ by varying the temperature ranges from $75{ }^{\circ} \mathrm{C}$ to $450{ }^{\circ} \mathrm{C}$. The LCR meter had a maximum six-digit resolution and a basic accuracy of $0.08 \%$. Figure $7 \mathrm{a}, \mathrm{b}$ depict the temperature-dependent variation in dielectric permittivity and dielectric loss of the prepared bulk sample at different frequency variations.

Some anomalies are observed at lower-end temperature values $\left(\sim 250{ }^{\circ} \mathrm{C}\right)$, which may be due to moisture and structural instability. Magnitude and dispersion in both dielectric permittivity and dielectric loss are increased with a rise in temperature (above $250{ }^{\circ} \mathrm{C}$ ) up to the instrument upper limit $\left(450^{\circ} \mathrm{C}\right)$. This is due to a high-temperature sintering process. The dielectric is either perfect or imperfect. A perfect dielectric refers a good insulator, but in the case of an imperfect dielectric, the dielectric permittivity attains both real and imaginary functional parts. The real and imaginary parts act oppositely to each other. The real part is denoted as the dielectric constant. Elevation in temperature increases the dielectric constant value, whilst the imaginary part decreases it. Thus, it reveals the electric dipole information [32,33].

The case of a dielectric with a small semiconducting effect (imperfect dielectric) occurs due to charge carriers such as electrons, but in the case of gahnite ferroan material (powder form), it possesses a band gap of $\sim 3.37 \mathrm{eV}$. The increase in dielectric constant at a higher degree of temperature reveals the presence of thermally activated charge carriers, whereas the imaginary part is referred to as the loss component of the material. The nature of the curve for both the dielectric constant and dielectric loss are similar to each other. The Arrhenius ac conductivity $(\log \sigma$ vs. $1000 / \mathrm{T})\left(\mathrm{K}^{-1}\right)$ study is depicted in Figure 8 at different frequency variations. The dispersion of conductivity occurs at high to low frequency values, with low $1000 / \mathrm{T})\left(\mathrm{K}^{-1}\right)$ values merged to a point and the order changed after that. The increase in the ac conductivity at a higher temperature denotes the negative temperature coefficient resistance (NTCR) behavior. The most common industrial applications of NTCR thermistors are found in modern electronic circuits [34]. The NTCR behavior enables the sample to be used for high-temperature sensing applications $[35,36]$. 


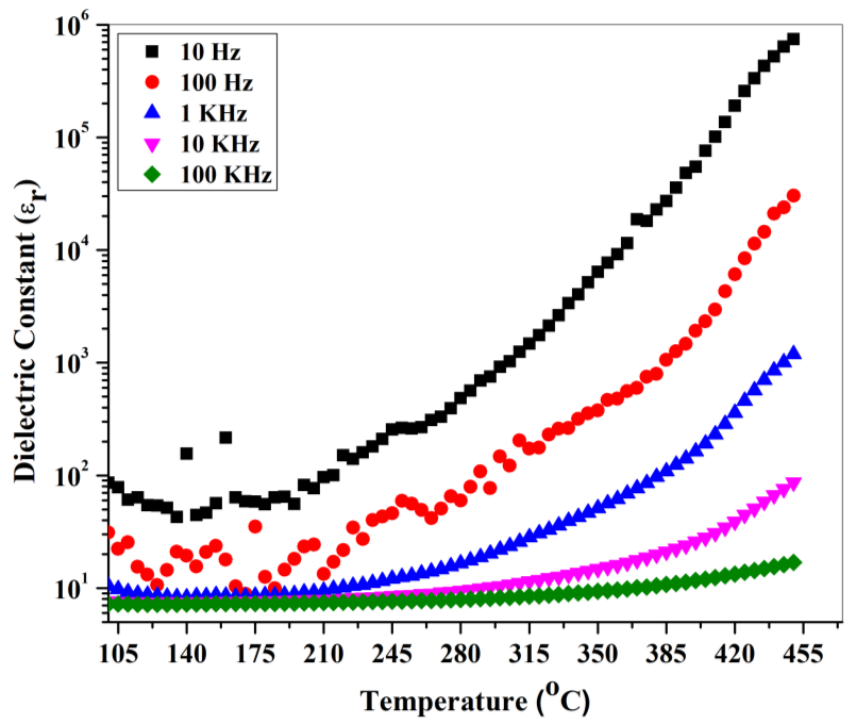

(a)

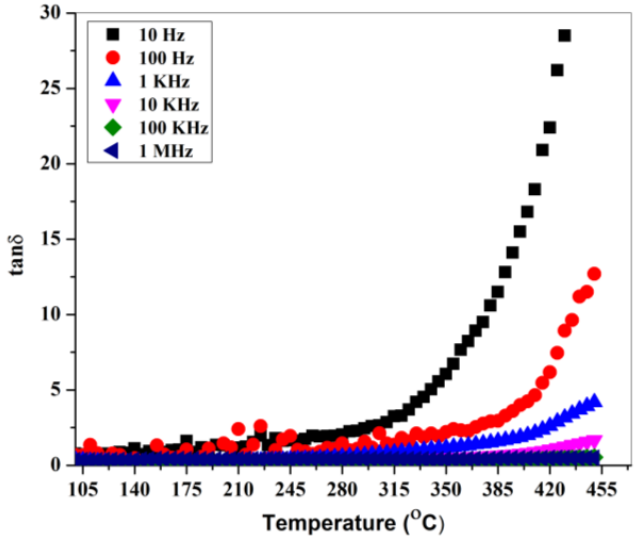

(b)

Figure 7. Temperature-dependent (a), dielectric permittivity and (b) dielectric loss of bulk gahnite ferroan composite, carried out at different frequencies.

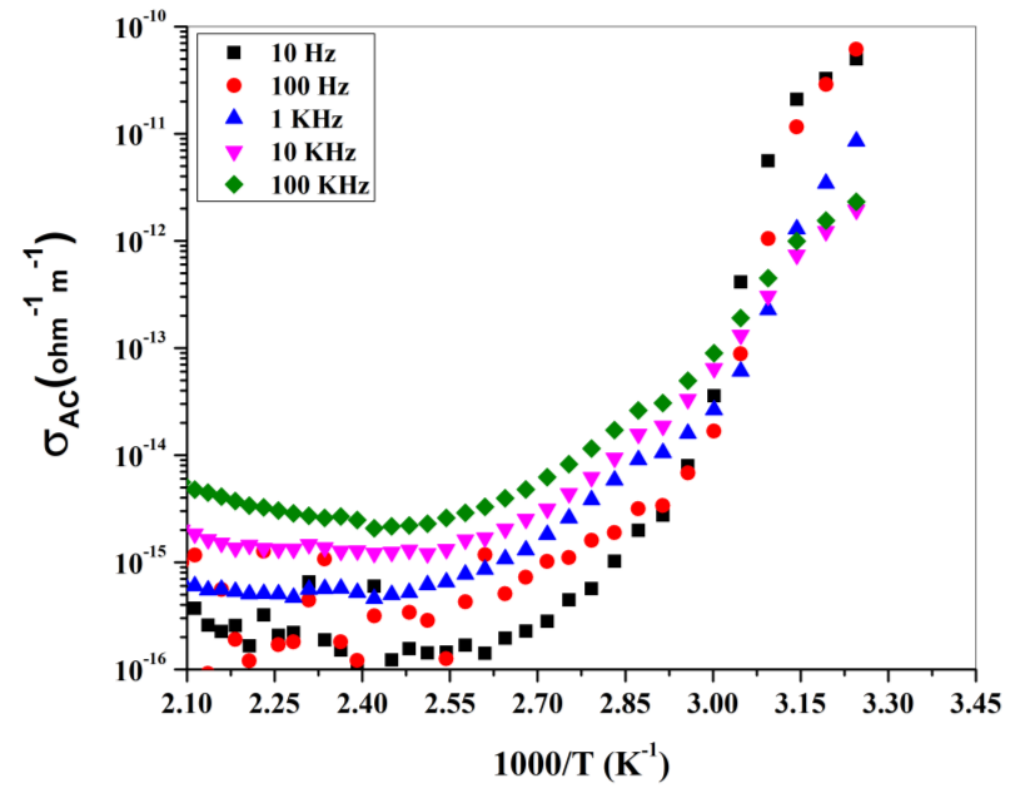

Figure 8. Arrhenius plot (ac conductivity study) of gahnite ferroan composite at different frequencies. 


\section{Conclusions}

In conclusion, the gahnite ferroan has been derived from a low value-added material, i.e., from fly ash, thus indicating the conversion of waste to a value-added product. The gahnite ferroan nano composite has been successfully synthesized by chemical techniques followed by a solid-state reaction route, to a high-purity material confirmed by JCPDS \# 85-1582. Surface morphology, structural appearance, texture and chemical composition of the samples were visualized using scanning electron microscopy in conjunction with an EDS system. The optical properties of the materials vary surprisingly, from nanocrystalline powder to the bulk form size of the material. The nano powder obstructs UV light, whereas the bulk form of the sample acts as a band pass filter for UV light. Hence, the same composition of gahnite ferroan composite may be used as a visible light filter or a UV light filter depending on the size of the product. In the case of dielectrics, a small semiconducting effect occurs due to charge carriers, such as electrons, but the gahnite ferroan material possesses a band gap of $\sim 3.37 \mathrm{eV}$. An Arrhenius ac conductivity study of the bulk gahnite ferroan sample at various frequency ranges shows NTCR behavior, which illustrates the high-temperature sensing applications of these materials.

Author Contributions: Conceptualization, H.P.T., P.P., D.K.M. and S.K.K.; methodology, H.P.T., P.P. and D.K.M.; Material Synthesis, S.K.K., S.S.P. and H.P.T.; formal analysis, P.P.; investigation, S.S.P. and D.K.M.; resources, D.K.M. and W.H.; data curation, H.P.T., A.K., R.S., G.H. and S.K.M.; writingoriginal draft preparation, H.P.T. and P.P.; writing-review and editing, W.H., H.P.T., P.P. and D.K.M.; supervision, S.K.K., A.K., G.H., S.K.M. and W.H. All authors have read and agreed to the published version of the manuscript.

Funding: This research received no external funding.

Institutional Review Board Statement: Not applicable.

Informed Consent Statement: Not applicable.

Data Availability Statement: Not applicable.

Conflicts of Interest: The authors declare no conflict of interest.

\section{References}

1. Blaxland, A.B. Occurrence of zinc in granitic biotites. Miner. Depos. 1971, 6, 313-320. [CrossRef]

2. Tulloch, A.J. Gahnite and columbite in an alkali-feldspar granite from New Zealand. Mineral. Mag. 1981, 44, 275-278. [CrossRef]

3. Frost, B.R. Ferroan gahnite from quartz-biotite-almandine schist, Wind River Mountains, Wyoming. Am. Mineral. 1973, 58, 831-834.

4. Sandhaus, D.J.; Craig, J.R. Gahnite in the metamorphosed stratiform massive sulfide deposits of the Mineral District, Virginia, USA. TMPM Tschermaks Mineral. Petrogr. Mitt. 1986, 35, 77-98. [CrossRef]

5. Gandhi, S.M. On the ferroan gahnite of Mamandur, Madras State, India. Mineral. Mag. 1971, 38, 528-529. [CrossRef]

6. Wang, A.; Zhang, C.; Sun, W. Fly ash effects: II. The active effect of fly ash. Cem. Concr. Res. 2004, 34, 2057-2060. [CrossRef]

7. Ahmaruzzaman, M. A review on the utilization of fly ash. Prog. Energy Combust. Sci. 2010, 36, 327-363. [CrossRef]

8. GB1596-88. Fly Ash Used in Cement and Concrete; University of New Brunswick: Fredericton, NB, USA, 1988.

9. Fulekar, M.H. Disposal of Fly Ash-An Environmental Problem. Int. J. Environ. Stud. 1986, 26, 191-215. [CrossRef]

10. Mohanty, J.K.; Guru, S.R.; Dash, P.; Pradhan, P.K. Fly Ash Management and Condition Monitoring of Ash Pond. Earth Syst. Environ. 2020, 5, 1-13. [CrossRef]

11. Berry, E.E.; Malhotra, V.M. Flyash for use in Concrete-A Critical Review. J. Am. Concr. Inst. 1980, 77, 59-73. [CrossRef]

12. Swanepoel, J.C.; Strydom, C.A. Utilisation of fly ash in a geopolymeric material. Appl. Geochem. 2002, 17, 1143-1148. [CrossRef]

13. Molkere, V.; Aleem, M.I.A.; Arumairaj, P.D. Geopolymer Concrete-A Review. Int. J. Eng. Sci. Emerg. Technol. $2012,1,118-122$.

14. Kluczka, J.; Trojanowska, J.; Zołotajkin, M. Utilization of fly ash zeolite for boron removal from aqueous solution. Desalin. Water Treat. 2015, 54, 1839-1849. [CrossRef]

15. Ghaedi, M.; Mosallanejad, N. Removal of Heavy Metal Ions from Polluted Waters by Using of Low Cost Adsorbents: Review. J. Chem. Heal. Risks 2013, 3, 7-22.

16. Wouterlood, H.J.; Bowling, K.M.G. Removal and Recovery of Arsenious Oxide from Flue Gases. Environ. Sci. Technol. 1979, 13, 93-97. [CrossRef]

17. Swami, D.; Buddhi, D. Removal of contaminants from industrial wastewater through various non-conventional technologies: A review. Int. J. Environ. Pollut. 2006, 27, 324-346. [CrossRef] 
18. Lekgoba, T.; Ntuli, F.; Falayi, T. Application of coal fly ash for treatment of wastewater containing a binary mixture of copper and nickel. J. Water Process Eng. 2021, 40, 101822. [CrossRef]

19. Gorai, S. Utilization of Fly ash for sustainable environment management. J. Mater. Environ. Sci. 2018, 9, $385-393$.

20. Kurajica, S.; Šipušić, J.; Zupancic, M.; Brautović, I.; Albrecht, M. $\mathrm{ZnO}-\mathrm{Al}_{2} \mathrm{O}_{3}-\mathrm{SiO}_{2}$ glass ceramics: Influence of composition on crystal phases, crystallite size and appearance. J. Non. Cryst. Solids 2021, 553. [CrossRef]

21. Yang, R.; Han, A.; Ye, M.; Chen, X.; Yuan, L. The influence of Mn/N-codoping on the thermal performance of $\mathrm{ZnAl}_{2} \mathrm{O}_{4}$ as high near-infrared reflective inorganic pigment. J. Alloys Compd. 2017, 696, 1329-1341. [CrossRef]

22. Pathak, N.; Gupta, S.K.; Sanyal, K.; Kumar, M.; Kadam, R.M.; Natarajan, V. Photoluminescence and EPR studies on Fe ${ }^{3+}$ doped $\mathrm{ZnAl}_{2} \mathrm{O}_{4}$ : An evidence for local site swapping of $\mathrm{Fe}^{3+}$ and formation of inverse and normal phase. Dalt. Trans. 2014, 43, 9313-9323. [CrossRef] [PubMed]

23. Ianoş, R.; Muntean, E.; Păcurariu, C.; Lazău, R.; Bandas, C.; Delinescu, G. Combustion synthesis of a blue Co-doped zinc aluminate near-infrared reflective pigment. Dye. Pigment. 2017, 142, 24-31. [CrossRef]

24. Danchevskaya, M.N.; Ivakin, Y.D.; Torbin, S.N.; Muravieva, G.P.; Ovchinnikova, O.G. Thermovaporous synthesis of complicated oxides. J. Mater. Sci. 2006, 41, 1385-1390. [CrossRef]

25. Molla, A.R.; Rodrigues, A.M.; Singh, S.P.; Lancelotti, R.F.; Zanotto, E.D.; Rodrigues, A.C.M.; Reza Dousti, M.; de Camargo, A.S.S.; Magon, C.J.; Silva, I.D.A. Crystallization, mechanical, and optical properties of transparent, nanocrystalline gahnite glass-ceramics. J. Am. Ceram. Soc. 2017, 100, 1963-1975. [CrossRef]

26. Visinescu, D.; Paraschiv, C.; Ianculescu, A.; Jurca, B.; Vasile, B.; Carp, O. The environmentally benign synthesis of nanosized CoxZn1-xAl ${ }_{2} \mathrm{O}_{4}$ blue pigments. Dye. Pigment. 2010, 87, 125-131. [CrossRef]

27. Sumathi, S.; Kavipriya, A. Structural, optical and photocatalytic activity of cerium doped zinc aluminate. Solid State Sci. 2017, 65, 52-60. [CrossRef]

28. Ma, C.; Chen, X.Y.; Bao, S.P. Generalized synthesis of 1-D nanoporous aluminates by using a sacrificial template especially evidenced in case of $\mathrm{ZnAl}_{2} \mathrm{O}_{4}: \mathrm{Eu}^{3+}$ phosphors. Microporous Mesoporous Mater. 2010, 129, 37-41. [CrossRef]

29. Tsai, M.T.; Chang, Y.S.; Huang, I.B.; Pan, B.Y. Luminescent and structural properties of manganese-doped zinc aluminate spinel nanocrystals. Ceram. Int. 2013, 39, 3691-3697. [CrossRef]

30. Ravikumar, B.S.; Nagabhushana, H.; Sunitha, D.V.; Sharma, S.C.; Nagabhushana, B.M.; Shivakumara, C. Plant latex mediated green synthesis of $\mathrm{ZnAl}_{2} \mathrm{O}_{4}: \mathrm{Dy}^{3+}$ (1-9 mol\%) nanophosphor for white light generation. J. Alloys Compd. 2014, 585, 561-571. [CrossRef]

31. Pattanaik, P.; Kamilla, S.K.; Das, D.P.; Mishra, D.K. Experimental and simulated study of electrical behaviour of ZnO film deposited on Al substrate for device applications. J. Mater. Sci. Mater. Electron. 2014, 25, 3062-3068. [CrossRef]

32. Huang, H.; Zhang, Y.; Huang, Z.; Kou, Z.; Yuan, X.; Ren, Z.; Zhai, Y.; Du, J.; Zhai, H. Magnetic behaviors of $\mathrm{Co}_{1}-\mathrm{xZnxFe} \mathrm{O}_{4}$ nano-particles. J. Appl. Phys. 2015, 117, 17E711. [CrossRef]

33. Mohanty, B.; Parida, B.N.; Parida, R.K. Structural, dielectric and magnetic behavior of BST modified rare earth ortho-ferrite $\mathrm{LaFeO}_{3}$. Ceram. Int. 2020, 46, 16502-16509. [CrossRef]

34. Feteira, A. Negative temperature coefficient resistance (NTCR) ceramic thermistors: An industrial perspective. J. Am. Ceram. Soc. 2009, 92, 967-983. [CrossRef]

35. Yu, Y.; Huang, Q.; Rhodes, S.; Fang, J.; An, L. SiCNO-GO composites with the negative temperature coefficient of resistance for high-temperature sensor applications. J. Am. Ceram. Soc. 2017, 100, 592-601. [CrossRef]

36. Neella, N.; Gaddam, V.; Rajanna, K.; Nayak, M.M. Negative temperature coefficient behavior of graphene-silver nanocomposite films for temperature sensor applications. In Proceedings of the 2016 IEEE 11th Annual International Conference on Nano/Micro Engineered and Molecular Systems, NEMS 2016, Sendai, Japan, 17-20 April 2016; Institute of Electrical and Electronics Engineers Inc.; pp. 329-332. 